DOI: http://dx.doi.org/10.24093/awejtls/vol2no3.1

\title{
D. H. Lawrence, America, and Classic American Literature: A Relationship of Attraction, Disappointment, and Abhorrence
}

\author{
Taher Badinjki \\ Department of English \\ Faculty of Arts \\ Al-Zaytoonah University, Amman, Jordan
}

\begin{abstract}
D.H. Lawrence's relationship with America and American literature is a relationship of attraction, disappointment, and abhorrence. This paper investigates Lawrence's increasing interest in American as a new and promising place, and records his attempts to emigrate there. It sheds light on his involvement in American public life and literary circles, and records his disappointment and frustration. It also records his critical views on the works of Benjamin Franklin, Fenimore Cooper, Edgar Allan Poe, Nathaniel Hawthorne, Herman Melville, Walt Whitman and other famous American literary figures. The final part offers a critical examination of his essays and shows how his highly personal feelings, disappointment, and experience of exile altered his tone and views on American culture and literature as seen in the third version of these Studies.
\end{abstract}

Keywords: America, attraction, emigrate, hatred, studies

Cites as: Badinjki, T. (2018). D. H. Lawrence, America, and Classic American Literature: A Relationship of Attraction, disappointment, and Abhorrence. Arab World English Journal for Translation \& Literary Studies, 2 (3). DOI: http://dx.doi.org/10.24093/awejtls/vol2no3.1 